\title{
Big Data Analytics Influence on FinancialPerformance and Market Value: Intellectual Capital as a Proxy
}

${\text { Zakaria } \text { Nejjari }^{{ }^{*}} \text {, HananeAamoum }}^{2}$

${ }^{1}$ National School of Commerce and Management, University Hassan II Casablanca, Morocco

${ }^{2}$ National School of Commerce and Management, University Hassan II Casablanca, Morocco

\begin{abstract}
Big data (BD) analytics is emerging as a valuable innovative research area for academics and professionals, showing the substantial requirement in an information-motivated economy focused on knowledge for answers to the market issues. It isn't simple to effectively utilize the emerging technology, and it's actually more difficult to evaluate the BD involvement in enhancing company performance. Furthermore, empirical research exploring the effects on financial performance and market value of the BD remain limited. In evaluating its impact on firm value, this research suggested employing the companies intellectual (IC) capital as a substitute for the BD efficiency deployment. This research utilized the VAIC technique to determine IC, through its principal constituents: capital employed efficiency, structural capital efficiency, human capital efficiency and subsequently applied the SEM method to examine the model fit. The data in this research comprise 29 Moroccan firms registered on the Casablanca Stock Exchange (CSE). These firms are part of 8 sectors: Food producers and processors, banks, Insurance, building and construction materials, participation and promotion real estate, distributors, mining, hardware, software and IT services. The chosen information covering a period of six years, from 2013 to 2019. The test findings indicated that capital employed efficiency and human capital efficiency affect positively and significantly the financial performance and market value.
\end{abstract}

\section{Introduction}

Several firms took big data (BD) as one of the focuses of their corporation policy and considering investing extensively in the technology, some of them didn't realize how to create added value of it [15]. Exploiting the nascent technology efficiently isn't simple, and examining BD analytics involvement in enhancing company value is as a matter of fact extremely harder $(8 ; 33)$. More substantively, the address of whether BD analytics has a considerable favorable effect on the companies was not yet fulfilled explicitly in academic [8]. Moreover, empirical analyses evaluating the big data analytics impacts on financial performance and market value stayed limited [17;20]. This research was intended at filling the void, creating appreciable knowledge to each educational and professional field. This investigation enhanced enormous associated discipline literature: $\mathrm{BD}$, information systems (IS), intellectual capital (IC) and organizational knowledge. The research results participated to the cumulative empirical testimony that big data analytics may aid businesses nevertheless of size increase their business performance given that the technology permits to firms to assist customers considerably better and do business significantly more successfully [15].

* Corresponding author:za.gmail@gmail.com 
[32][Cited in 33] indicated that if we can' $t$ measure something, it can' $t$ be administered and controlled. It is hard to measure the big data performance in companies, which in occurrence gets it an alarming assignment to determine the big data analytics implementation impacts on corporations[20;33]. To simplify the big data effects evaluation on financial performance and market value, this research adopts the IC as a substitute for BD analytics efficiency.

The current investigation attempted to respond to the subsequent inquiry request: How does $\mathrm{BD}$, consisting of the three measures of intellectual capital effectiveness (CEE, SCE and $\mathrm{HCE}$ ), influence market value and financial performance?

As proceeds this analysis is planned. The first section asserts the theoretical context and a short literature review that focuses on the big data analytics deployment ultimate objectives, then initiates the intellectual capital fundamental notions perceived as organizational knowledge and highlight the connection between BD performance and intellectual capital. In second section the study methodology is introduced. Discussion and implications are presented in the third section. The research ends with the conclusions section.

\section{Theoretical background and literature review}

\subsection{Theoretical Background}

Different theories that hypothesize diverse corporation views exist. While there may be several divergences in whatever these theories confirm, the vital issue all of them attempt to answer what gets companies distinct from each other [9]. How is this firm especially better at battling its adversaries than another [2]? How can a company perform extremely more efficient on the market than others in an identical sector [18]?

Amongst the corporations highly stated theories in the literature is the resource-based view (RBV). This theory asserts that strategic assets aid a company fight better and function more successfully given that they are precious, scarce, incomparable, and interchangeable [10].

\subsection{Literature Review}

\subsubsection{Organizational Knowledge, Big Data analytics (BD) and Intellectual capital (IC)}

BD may aid associations to create value-added in almost all facets of the industry process. Utilizing BD analytics, enterprises intends to receive practical knowledge into an enormous data amount, and then maximize the industry intelligence extorted from the data to enhance firm results $[6 ; 28]$.

In different terms, the primary aims of applying $\mathrm{BD}$ in companies are to establish further organizational knowledge operational and information that may be utilized to maintain satisfactory privilege and enhance firm value. Hence, corporate organizational knowledge evaluation can illustrate the big data deployment performance. Intellectual capital is commonly recognized to contain three key elements: $\mathrm{HC}, \mathrm{SC}$, and $\mathrm{RC}$ [22]. Human Capital (HC) indicates the communal knowledge, abilities, creativity, capability, and even employee excitement [31]. Structural Capital (SC) reflects the ingrained capability and systematized knowledge created by an organization system, procedures, information systems, technology designs, structures, and business plan [10]. Relational Capital (RC) constitutes the value produced across the connection with customers, providers, and other exterior investors [22]. Organizational knowledge and intellectual capital (IC) are 
identical when both are seen from the standpoint of stable resources [14]. In other terms, firm intellectual capital is organizational knowledge that has been regularized to be employed in establishing valuesetting and accomplishing excellent value [14].

\subsubsection{Intellectual Capital (IC): A Big Data Proxy}

The fundamental deploying BD objective is to establish organizational knowledge that would be utilized to maintain competitive advantage [28]. Moreover, intellectual capital can be perceived as organizational knowledge that may aid corporations increase competitiveness and attain better performance [14]. Correspondingly, intellectual capital (IC) measurement can be exploited as a substitute for the efficiency of the BD implementation in companies. In other terms, it is rational to assess enterprise IC and then apply its measurement in examining the big data effects on financial performance and market value, which fixes study problems.

\subsubsection{VAIC method, Intellectual Capital (IC), Financial Performance}

The intellectual capital (IC) notion is supposed to be initially mentioned by Kenneth in 1969, cited in [11]. Ever since, IC in managerial interpretation gets generally realized because of Stewart's papers regarding "brainpower" released by [7] in 1991, cited in [14].

IC literature introduces a significant method diversity that would be employed to evaluate intellectual capital in companies [28]. Amongst disparate methods, we can invoke the VAIC (Value Added Intellectual Coefficient) method, one of the famous instruments to evaluate intellectual capital efficiency. Established by Pulic[25], VAIC design intends to determine the performance using three predictors (CEE, SCE, HCE). The values may be exploited to constitute the intellectual capital evaluation in businesses [19]. VAIC is, giving to [13], stronger than other techniques for calculating intellectual capital.

The literature review endorses the accumulated empirical evidence that intellectual capital influences financial performance and market value considerably and positively influence on financial performance and market value [16]. Nevertheless, the findings differed significantly from one business to another, or from one region to a separate one, considering the intellectual capital elements effect-Human capital (HC); Structural capital (SC); relational capital (RC), or the efficiency elements impact-Human capital efficiency (HCE); Structural capital efficiency (SCE); Capital employed efficiency (CEE), on corporate strategy results.

\section{Research Methodology}

\subsection{The sample}

The sample in this study consists of 29 Moroccan companies listed on the Casablanca Stock Exchange. These companies belong to 8 economic sectors (according to the official classification of the Casablanca stock exchange): Food producers and processors (4), banks (4), Insurance (3), Building and construction materials (3), Participation and promotion real estate (3), Distributors (4), Mining (3), Hardware, software and IT services (5). The selected data cover a period of six years, from 2013 to 2019. 


\subsection{VAIC (Value Added Intellectual Coefficient)}

The VAIC Technique is derived from the value added notion that is an evaluation illustrating the personal participation, administration, and alternative company assets to produce value [26].

The first step towards calculating the VAIC is to calculate the value added (VA). The VA is calculated according to the methodology proposed by [27].

The Second stage, the capital employed (CE), the human capital (HC) and the structural capital (SC) are calculated:

$$
\begin{gathered}
C I=\text { Total assets * } \text { - intangible assets } \\
C H=\text { Total investment on employees (wages, salaries, etc.) } \\
S C=V A-H C
\end{gathered}
$$

Finally, VAIC and its three components are calculated as follows:

$$
\begin{gathered}
C E E=V A / C E \\
H C E=V A / H C \\
S C E=S C / V A \\
V A I C=C E E+H C E+S C E
\end{gathered}
$$

\subsection{Independent and dependent variables}

Intellectual capital was presented in this research as BD proxy and a key indicator symbolized by three predictors:

CEE, HCE and SCE $[5 ; 12]$. Such efficiency indicators were thenemployed as explanatory variables [34].

The response variables utilized in the study are: Return-on-equity (ROE) and return-onassets (ROA) indicating financial performance, market to book value (MBV) indicating market value [16].

\subsection{The Model Test}

SEM (structural equation modeling) is a commonly selected method by scholars through fields [4]. SEM is regularly utilized in the intellectual capital literature to examine the intellectual capital impact on company performance [4]. A SEM examination was conducted applying AMOS to examine the research model. The estimation was performed utilizing MLE (maximum likelihood estimation). MLE is a method applied to disclose the most probable function(s) that would interpret examined information [21].

\subsection{Research Hypotheses and Conceptual Model}

The succeeding hypotheses were adopted using the enterprise theories and the literature:

- H1: Capital employed efficiency (CEE) affects the financial performance.

- H1a: Capital employed efficiency (CEE) affects the ROE (Return-on-equity).

- H1b: Capital employed efficiency (CEE) affects the ROA (Return-on-assets).

- H2: Capital employed efficiency (CEE) affects market to book value. 
- H3: Human Capital efficiency (HCE) affects the financial performance.

- H3a: Human Capital efficiency (HCE) affects the ROE (Return-on-equity).

- H3b: Human Capital efficiency (HCE) affects the ROA (Return-on-assets).

- H4: Human Capital efficiency (HCE) affects the market to book value.

- H5: Structural Capital efficiency (SCE) affects the financial performance.

- H5a: Structural Capital efficiency (SCE) affects the ROE (Return-on-equity).

- H5b: Structural Capital efficiency (SCE) affects the ROA (Return-on-assets).

- H6: Structural Capital efficiency (SCE) affects the market to book value.

The succeeding conceptual model is adopted using the literature:

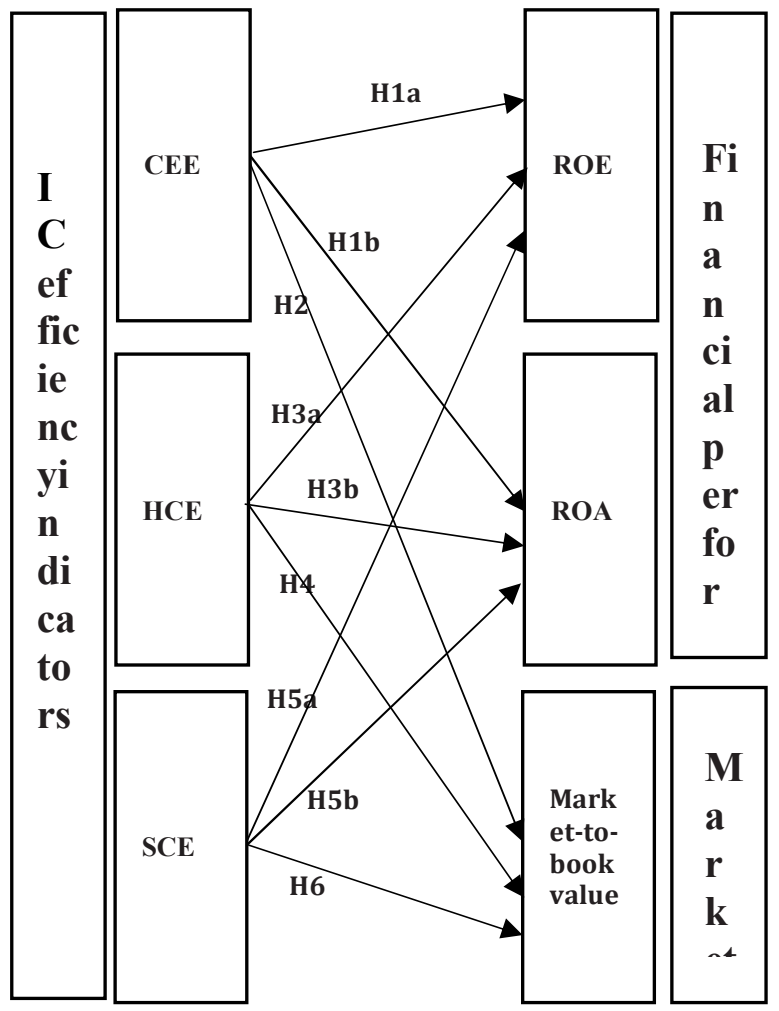

Fig1. Conceptual Model for Research

\section{Results}

The following fit indices were used for the evaluation of the model fit:

- $\quad \chi^{2}$ test (Chi-square).

- The comparative fit index (CFI).

- The goodness of fit index (GFI)

- $\quad$ Normed Fit Index (NFI). 
The root mean square error of approximation (RMSEA)

The $\chi 2$ test evaluated the global model fit [13]. To reflect an excellent model, the test should beinsignificant

( $>$

$0.05)$

[13].

The findings demonstrated that the model fit the data: chi-square $=3.768$, degrees of freedom $=2$, and $\mathrm{p}$ level $=0.184(>0.05)$. Table 1 outlines the fit goodness significance and standard values:

Table1.Goodness of Fit Indices.

\begin{tabular}{|l|l|l|}
\hline The fit goodness & Standard values & $\begin{array}{l}\text { The study } \\
\text { values }\end{array}$ \\
\hline CFI & $>0.90$ & 0.962 \\
\hline NFI & $>0.90$ & 0.939 \\
\hline GFI & $>0.90$ & 0.945 \\
\hline RMSEA & $<0.08$ & 0.077 \\
\hline
\end{tabular}

The research results show that $\mathrm{H} 1$ (H1a, H1b); H2; H3 (H3a, H3b); H4 are accepted. The findings are presented below (Table 2, Table 3):

Table 2.Hypotheses testing results.

\begin{tabular}{|l|l|l|}
\hline Hypothesis & $\beta$ & P value \\
\hline H1a & 0.394 & 0.000 \\
\hline H1b & 0.458 & 0.000 \\
\hline H2 & 0.721 & 0.000 \\
\hline H3a & 0.295 & 0.000 \\
\hline H3b & 0.442 & 0.000 \\
\hline H4 & 0.801 & 0.000 \\
\hline H5a & -0.011 & 0.112 \\
\hline H5b & 0.228 & 0.345 \\
\hline H6 & -0.432 & 0.598 \\
\hline
\end{tabular}

Table3.Testing results summary.

\begin{tabular}{|l|l|l|}
\hline Hypothesis & Path & Result \\
\hline $\mathrm{H} 1 \mathrm{a}$ & $\begin{array}{l}\mathrm{CEE} \longrightarrow \\
\mathrm{ROE}\end{array}$ & Accepted \\
\hline $\mathrm{H} 1 \mathrm{~b}$ & $\begin{array}{l}\mathrm{CEE} \longrightarrow \\
\mathrm{ROA}\end{array}$ & Accepted \\
\hline $\mathrm{H} 2$ & $\begin{array}{l}\mathrm{CEE} \longrightarrow \\
\mathrm{MBV}\end{array}$ & Accepted \\
\hline $\mathrm{H} 3 \mathrm{a}$ & $\begin{array}{l}\mathrm{HCE} \longrightarrow \\
\mathrm{ROE}\end{array}$ & Accepted \\
\hline $\mathrm{H} 3 \mathrm{~b}$ & $\begin{array}{l}\mathrm{HCE} \longrightarrow \\
\mathrm{ROA}\end{array}$ & Accepted \\
\hline $\mathrm{H} 4$ & $\begin{array}{l}\mathrm{HCE} \longrightarrow \\
\mathrm{MBV}\end{array}$ & Accepted \\
\hline
\end{tabular}




\begin{tabular}{|l|l|l|}
\hline $\mathrm{H} 5 \mathrm{a}$ & $\begin{array}{l}\mathrm{SCE} \longrightarrow \\
\mathrm{ROE}\end{array}$ & Rejected \\
\hline $\mathrm{H} 5 \mathrm{~b}$ & $\begin{array}{l}\mathrm{SCE} \longrightarrow \\
\mathrm{ROA}\end{array}$ & Rejected \\
\hline $\mathrm{H} 6$ & $\begin{array}{l}\mathrm{SCE} \longrightarrow \\
\mathrm{MBV}\end{array}$ & Rejected \\
\hline
\end{tabular}

H1 (H1a, H1b) suggested that CEE affects the ROE and ROA. The outcomes $(\beta=0.394$, $\mathrm{p}<0.001 ; \beta=0.458, \mathrm{p}<0.001)$ fully backed this hypothesis validating that CEE has a positive and significant impacts on financial performance. Same for H3 (H3a, H3b), HCE has a positive and significant impacts on financial performance $(\beta=0.295, p<0.001 ; \beta=$ $0.442, \mathrm{p}<0.001)$. The research results are compatible with those discovered in the past analyses performed by [12] and [16]. Nevertheless, these findings are distinct from those retrieved by[23] and [19]. In those investigations, the researchers uncovered that the influence of either CCE, HCE or intellectual capital on company financial performance was insignificant.

$\mathrm{H} 2, \mathrm{H} 4$ recommended that CEE and HCE affects the MBV. The findings $(\beta=0.721, p$ $<0.05 ; \beta=0.0 .801, p<0.05$ ) demonstrated that CEE and HCE have a positive and significant impacts on market value. The analysis conclusions are steady with those achieved by [29] and [16]. Regardless, these findings are varied from those got by [19].In this research, the author discovered that the effect of CEE or HCE on market value was insignificant.

The remaining hypothesis ( $\mathrm{H} 5$; H6), proposed that SCE have a significant impact on ROE, ROA and MBV, are not accepted sustained with the results obtained by [19].

\section{Discussion and Implications}

As an emergent discipline, big data analytics change with a torsion rapidity, that gets the researchers and practitioners interest [6]. The findings from 437 societies survey conducted by the investigation company [8]demonstrated that $75 \%$ of observed firms are investing or scheduling to spend on big data analytics programs over the next few years.

Nevertheless, the continual study remarkably disclosed that $43 \%$ of the firms that orchestrated to invest and 38\% are initially invested in big data weren' $\mathrm{t}$ convinced concerning what should be the investment outcomes-whether or not their investments generate a meaningful ROI [8]. The major problem is that these firms either didn' $t$ understand how to assess or couldn' t efficiently assess the BD performance that allows them to obtain competitive advantage [1]. The results of this research helped to the amassed empirical confirmation that big data analytics would assist companies nonetheless of dimensions enhance their business efficiency and boost viability given that the technology allows corporations to accommodate consumers extremely better and conduct business more successfully [6;24]. Notably, the current analysis solved via empirical proof to the vital issue of whether or not big data gets out crucial business significance that has been withdrawn [3]. The literature analysis discovered that case analysis has been famous in big data analytics research, particularly regarding its effects on firm value. Through the causal modeling method application, this research should aid to enhance the research trends in BD investigation and offer a paradigm for the forthcoming study of BD's influence. Moreover, the research results will disclose which big data element-capital employed, structural, or human capital - might offer the highly considerable impact on company business decisions. The models testing outcomes shown that HCE and CEE have a considerable favorable 
influence on business profitability, which underscored the notable financial capital and human involvement in the big data technology effects.

\section{Conclusion}

In conclusion, several obstacles can be discovered on the trajectory to wealth of companies' big data deployment [15]. Utilizing the nascent technology effectively has its particular difficulties, and handling big data properly to enhance industry performance is actually more difficult $[15 ; 24]$. Though, firms have obviously acknowledged that information-driven choice are those they must produce [30]. Several businesses of various magnitudes have reviewed big data as a leading concern that must receive a major interest from the upper managers (Forbes, 2015). All associations that have placed plenty of initiatives and investments in their BD technique would gather the outcomes through enhancing firm performance.

The main study weakness is that just companies listed in the Casablanca stock exchange are contained in the analysis. Additional limit is that structural equation modeling was utilized in examining the conceptual model. While structural equation modeling is a universal technique [30], this method has its constraints. In research with study sample magnitude narrower than 200, the method might overcompensate real models. Future study might contain each public registered and privately detained firms in the sample. Academics could employ a bigger panel data sample that are gathered for five years, or more. Other studies could examine conducting a complete substance analysis on the connection between big data analytics and intellectual capital.

\section{References}

1. Arora, B., \& Rahman, Z. 2016. Using Big Data Analytics for Competitive Advantage. International Journal of Innovative Research and Development, Vol. 5, Issue 2, 248 - 250.

2. Barney, J.B. 1991. Firm resources and sustained competitive advantage. Journal of Management, Vol. 17, Issue 1, $99-120$.

3. Chen, X., \&Siau, K. 2012. Effect of Business Intelligence and IT Infrastructure Flexibility on Organizational Agility. In Proceedings of the 33rd International Conference on Information Systems, Orlando, Florida.

4. Deep, R., \&Narwal, K. P. 2014. Intellectual capital and its association with financial performance: A study of Indian textile sector. International Journal of Management \& Business Research, Vol. 4, Issue 1, 43 - 54.

5. Duho, K.C.T. and Onumah, J.M. 2019. Bank diversification strategy and intellectual capital in Ghana: an empirical analysis. Asian Journal of Accounting Research, Vol. 4 No. 2, pp. 246-259.

6. Elisabetta, R. \&Claudio, V. 2017. Investments in big data analytics and firm performance: an empirical investigation of direct and mediating effects. International Journal of Production Research, Taylor \& Francis, 56 (15), pp.5206 - 5221.

7. Forbes Insight. 2015. Analytics: Don't Forget the Human Element-Data and Analytics Impact Index. Management and Business Operations, From EY .

8. Gartner. 2015. Gartner survey shows more than 75 percent of companies are investing or planning to invest in big data in the next two years.

9. Grant, R. M. 1996. Towards A knowledge-based theory of the firm. Strategic Management Journal, Vol. 17, Issue Winter Special, 109 - 122.

10. Han, Y., \& Li. D. 2015. Effects of intellectual capital on innovative performance: The role of knowledge-based dynamic capability. Journal of Knowledge Management, Vol. 53, Issue $1,40-56$.

11. Kaya, F., Sahin, G., \&Gurson, P. 2010. Intellectual capital in organizations. Problems and Perspectives in Management, Vol. 8, Issue 1, 153 - 160. 
12. Khalique, M., Hina, K., Ramayah, T. and Shaari, J.A.N.b. 2020. Intellectual capital in tourism SMEs in Azad Jammu and Kashmir, Pakistan. Journal of Intellectual Capital, Vol. 21 No. 3, pp. 333-355.

13. Khanhossini, D., Nikoonesbati, M., K., Heire, H., \&Moazez, E. 2013. Investigating of relationship between intellectual capital and financial performance in MAPNA group companies.

14. Kianto, A., Ritala, P., Spender, J., \&Vanhala, M. 2014. The interaction of intellectual capital assets and knowledge management practices in organizational value creation. Journal of Intellectual capital, Vol. 15, Issue 3, 362-375.

15. Liu, C.H. \&Mehandjiev, N. 2020. The Effect of Big Data Analytics Capability on Firm Performance: A Pilot Study in China.

16. Maditinos, D., Chatzoudes, D., Tsairidis, C.and Theriou, G. 2011. The impact of intellectual capital on firms' market value and financial performance. Journal of Intellectual Capital, Vol. 12 No. 1, pp. 132-151.

17. Maroufkhani, P. \& Wagner, R. \& Wan Ismail, W.K. \&Baroto, M. \&Nourani, M. 2019.Big Data Analytics and Firm Performance: A Systematic Review. Information.

18. Mehri, M., Umar, M.S., Saeidi, P., Hekmat, R.K., \&Naslmosavi, S. 2013. Intellectual Capital and Firm Performance of High Intangible Intensive Industries: Malaysia Evidence. Asian Social Science, Vol. 9, Issue 9, 146 - 154.

19. Morariu, C. 2014. Intellectual capital performance in the case of Romanian public companies. Journal of Intellectual Capital, Vol. 15, Issue 3, 392 - 410.

20. Müller, O. \& Fay, M. \&Brocke, J. 2018. The Effect of Big Data and Analytics on Firm Performance: An Econometric Analysis Considering Industry Characteristics.Journal of Management Information Systems.

21. Myung, I. J. 2003. Tutorial on maximum likelihood estimation. Journal of Mathematical Psychology, Vol. 47, Issue 2003, 90 - 100.

22. Nemati, S., Jalilian, H. R., \&Akbari, P. 2013. Investigate the relationship between intellectual capital and company performance. Scientific Journal of Pure and Applied Sciences, Vol. 2, Issue 12, $379-385$.

23. Oppong, G., Pattanayak, J., \& Irfan, M. 2019. Impact of intellectual capital on productivity of insurance companies in Ghana.Journal of Intellectual Capital, 20(6), 763-783.

24. Popovič, A. \& Hackney, R. \&Tassabehji, R. \& Castelli, M. 2016. The impact of big data analytics on firms' high value business performance. Information Systems Frontiers. 1-14.

25. Pulic, A 1998. Measuring the performance of intellectual potential in knowledge economy.

26. Ragab, M., \&Arisha, A. 2013. Knowledge management and measurement: a critical review. Journal of Knowledge Management, Vol. 17, Issue 6, 873 - 901.

27. Riahi-Belkaoui, A. 2002. Intellectual Capital and Firm Performance of U.S. Multinational Firms: A Study of the Resource-Based and Stakeholder Views. SSRN Electronic Journal.

28. Samsudeen, S.N. 2020. Impact of Big Data Analytics on Firm Performance: Mediating Role of Knowledge Management International Journal of Advanced Science and Technology, Vol 29, issue 6, 144-157.

29. Sarmadi, S. 2013. Investigating of relationship between intellectual capital and financial performance of Petrochemical Companies listed in Tehran Stock Exchange. Social Science Research Network.

30. Strawn, G.O. 2012. Scientific research: How many paradigms? EDUCAUSE Review, Vol. 47, Issue 3, $26-34$.

31. Sveiby, K.E. 1997. The New Organizational Wealth: Managing and Measuring KnowledgeBased Assets. New York, NY: Berrett-Koehler.

32. Thamir, A. \&Poulis, E. 2015. Business intelligence capabilities and implementation strategies. International Journal of Global Business, 8(1), 34 - 45.

33. Vishnu, S., \& Gupta, V. 2014. Intellectual capital and performance of pharmaceutical firms in India. Journal of Intellectual Capital, 15(1), 83 - 99.

34. Wang, Y., Su, X., Wang, H. and Zou, R.2019. Intellectual capital and technological dynamic capability: evidence from Chinese enterprises. Journal of Intellectual Capital, Vol. 20 No. 4, pp. 453-471. 